\title{
Lagunes des Landes de Gascogne - Anthropisation des milieux humides de la Grande Lande
}

Jean-Claude Merlet

\section{(QpenEdition \\ Journals}

Édition électronique

URL : http://journals.openedition.org/adlfi/7791

ISSN : 2114-0502

Éditeur

Ministère de la culture

Référence électronique

Jean-Claude Merlet, «Lagunes des Landes de Gascogne - Anthropisation des milieux humides de la Grande Lande », ADLFI. Archéologie de la France - Informations [En ligne], Aquitaine, mis en ligne le 01 mars 2007, consulté le 02 mai 2019. URL : http://journals.openedition.org/adlfi/7791

Ce document a été généré automatiquement le 2 mai 2019.

(C) Ministère de la Culture et de la Communication, CNRS 


\title{
Lagunes des Landes de Gascogne - Anthropisation des milieux humides de la Grande Lande
}

\author{
Jean-Claude Merlet
}

Identifiant de l'opération archéologique : 025100

Date de l'opération : 2007 (PC)

1 Commencé en 2004, le PCR s'est achevé en 2007. Pour cette dernière année du programme, les investigations de terrain ont été ciblées et l'accent a été mis sur certains thèmes susceptibles d'apporter des nouveautés à l'échelle régionale dans des domaines jusqu'alors très peu explorés. C'est ainsi que des diagnostics par sondages ont été réalisés notamment sur une occupation du Mésolithique et un atelier potier du bas Moyen Âge.

\section{La formation des lagunes (J.-P. Texier)}

3 La région d'Hostens, où la densité des plans d'eau appelés "lagunes » est très forte, bénéficie désormais d'un ensemble de données significatives sur plusieurs systèmes lagunaires. Une étude complète a été menée sur un système-type : la lagune du Bois à Hostens (Gironde). Les datations radiocarbone de la tourbe et des niveaux organiques périphériques de cette lagune donnent des résultats récents (vers $2000 \mathrm{BP}$ ), obligeant à reconsidérer l'hypothèse d'une genèse périglaciaire de ces formes. La question d'une formation synchrone des lagunes du plateau landais demeure posée.

Palynologie (D. Galop)

5 La base de la tourbière de la lagune X1 à Saint-Magne (Gironde) est datée à 2200 BP et la colonne de tourbe, épaisse de près de $2 \mathrm{~m}$, couvre la période historique : c'est donc là encore une date récente. Si l'ancienneté de certaines tourbières de lagunes semble acquise, il est de plus en plus évident que ces dépôts organiques ont pu commencer à s'accumuler à différentes périodes. Le début de l'Holocène n'a pas été rencontré dans les séquences étudiées. 

Moyen Âge de Saugnacq-Est à Saugnac-et-Muret (Landes) s'avère un habitat (sans doute $\mathrm{VII}^{\mathrm{e}}$ s.-VIII ${ }^{\mathrm{e}}$ s.), un des premiers repérés dans les Landes de Gascogne. L'axe de recherche sur les productions potières au bas Moyen Âge bénéficie cette année de la fouille d'une tessonnière à Saint-Symphorien (Gironde) et de la mise au jour de plusieurs nouveaux ateliers, du nord au sud de la région. Parallèlement, l'aire de diffusion du centre potier de Beylongue (Landes) est peu à peu circonscrite, avec de nouvelles données tant sur les ateliers que sur des sites de consommation situés dans un rayon d'une dizaine de kilomètres autour de Beylongue.

16 La mise en place d'une journée d'étude à Saugnac-et-Muret (Landes), à l'initiative de G. Belbéoc'h, sur le thème de la céramique, a connu un franc succès et l'initiative devrait être reconduite annuellement.

\section{Conclusion}

18 Au terme des quatre années du programme, le bilan de ce projet collectif est largement positif. Malgré la difficulté d'accès au sol tenant à l'omniprésence de la forêt, les résultats scientifiques sont fructueux. Les données accumulées sont importantes:210 sites nouveaux ont été répertoriés et étudiés, neuf d'entre eux ayant fait l'objet d'une évaluation par sondages.

作

- cadre climatique et végétal des occupations humaines depuis 8000 ans ; 
27 Merlet Jean-Claude et l'équipe du PCR

\section{INDEX}

Index géographique : Aquitaine

operation Projet collectif de recherche (PCR)

peuple Azilien

Thèmes : amas de débitage, artisanat, atelier de potier, céramique médiévale, climatologie, datation isotopique, habitat, industrie lithique, occupation du sol, palynologie, poix, radiocarbone, silex, tourbière, zone humide

Index chronologique : Antiquité, Épipaléolithique, Mésolithique, âge du Fer, Néolithique

\section{AUTEURS}

JEAN-CLAUDE MERLET

BEN 